\title{
Congenital Ankyloblepharon
}

National Cancer Institute

\section{Source}

National Cancer Institute. Congenital Ankyloblepharon. NCI Thesaurus. Code C87077.

A cong enital abnormality in which the margins of the upper and lower eyelids are fused together by bands of tissue. 